\title{
Managing the Classroom for Creativity
}

\author{
Molly A. James ${ }^{1,2}$ \\ ${ }^{1}$ University of Central Lancashire, Preston, UK \\ ${ }^{2}$ Kent Place School, Summit, NJ, USA \\ Email: majfoil@aol.com
}

Received 4 May 2015; accepted 16 June 2015; published 19 June 2015

Copyright (C) 2015 by author and Scientific Research Publishing Inc.

This work is licensed under the Creative Commons Attribution International License (CC BY).

http://creativecommons.org/licenses/by/4.0/

(c) (i) Open Access

\section{Abstract}

Enhancing student creativity is an educational goal, and increasingly, a global imperative. In the current educational context of the United States, this is a formidable task. I have struggled with this issue as an MA student, and as an educator. As an MA student I examined learning environments that support and enhance creativity, and received my Masters in Creative Thinking. As an educator at an academically rigorous $\mathrm{N}-12$ grade school, I endeavor daily to encourage deep thinking, academic excellence, and great creativity in my students. This paper expresses the voice of the researcher, and the voice of the passionate educator. This paper suggests it is possible to establish creativity-enhancing learning environments. It offers an understanding of creativity and its inherent connection to learning. Teresa Amabile's highly regarded workplace assessment inventory, KEYS, is presented and explored as a classroom management style that encourages creativity and achievement. Her theory suggests we, as educators, have the power to enhance our students' creativity by positively impacting our classroom environment. I map her approach onto two highly successful creative learning approaches-El Sistema and Reggio Emilia, and then interrogate and reflect upon the presence of KEYS in my own practice. Finally I offer suggestions for pre-service and in-service professional development to support educators as we work to empower our students to grow their creativity now and in the future.

\section{Keywords}

Creativity, Creativity and Learning, Creativity in the Classroom, Classroom Management, Amabile KEYS, Reggio Emilia, El Sistema

\section{Introduction}

As the world becomes more complex, the ability to think and act creatively becomes increasingly important. New opportunities and challenges will arise that invite exploration and demand inquiry and resolution. The uniqueness of these opportunities and challenges will require adroit thought that is steeped in knowledge and un- 
derstanding, and open to novelty and possibility (Azzam, 2009).

Educators have always been champions of knowledge. Many now suggest they become champions of creativity as well. In this way educators can empower students to use their knowledge to engage with the opportunities and challenges of today and tomorrow, see possibilities, and create innovations that will change the world for the better (Azzam, 2009; Wagner, 2014, Mindshift, 2015).

The task set for the educators and educational system in the United States is twofold-focus on cultivating creativity while engaging students in academic excellence that produces academic achievement. Many educators, however, feel unprepared to include creativity in their curricula. Some feel the weight of high-stakes testing, and the pressure to narrow the curriculum and teach to the test. Others do not fully understand creativity or its connection to learning. They perceive creativity and academic achievement as adversaries instead of allies. Still others lack the training needed to successfully manage their classroom for creativity.

In this paper, I offer an understanding of creativity that might enable teachers to include it in their classrooms and curricula. I offer findings from my MA research, which suggests a method of classroom management that is capable of enhancing creativity and learning. I interrogate my classroom management and teaching practice, and offer my findings and reflections. Finally, I suggest ways pre-service and in-service teacher development might better prepare and support educators, as they strive to cultivate academic excellence and creativity.

\section{Understanding Creativity and Learning}

A common misunderstanding of creativity suggests it has little connection to learning. Creativity researchers suggest just the opposite. They argue creativity benefits from, and enhances, learning (Kaufman \& Beghetto, 2009; Mindshift, 2015; Hennessey \& Amabile, 1987; Cropley, 2006).

For many researchers, creativity is the ability to generate new products, or conceive of unique and original ideas or things that are useful and appropriate. Creativity involves observing, seeing possibilities, finding problems, taking risks, making mistakes, failing, thinking, rethinking, trying new things, solving problems, and sharing the process and product (Torrance, 1977). Creativity is appropriate and active in all domains, even those generally seen as purely academic. Consider Albert Einstein, Pablo Picasso, composer Igor Stravinsky, poet T. S. Elliot, composer Martha Graham and political and spiritual leader Mahatma Gandhi (Gardner, 1993). Thinking and acting creatively in science, art, music, literature, politics and religion, they transformed their fields of expertise, and impacted the world.

Children are natural creatives. They often exhibit their creativity in free play, investigation and exploration. However, since their knowledge, understanding and experience are naive compared to the adults that surround them, children's creativity is often not perceived as particularly novel, nor useful by the adults. Therefore, children's creativity is sometimes disregarded, or devalued with the comment “Oh, isn't that cute!”. This is unfortunate as this beginning creativity holds the potential for increased understanding, new knowledge, and more sophisticated creativity as they grow and learn (Beghetto \& Kaufman, 2007; Runco, 2008).

Beghetto and Kaufman give credit to this beginning creativity by advancing it as an actual level of creativity, mini-c creativity, in their 4-C model of creativity. They distinguish four levels of creativity: big-c, pro-c, little-c and mini-c creativity. Big-c and pro-c creativity are preeminent levels of creativity. Little-c and mini-c creativity are smaller, more ordinary levels of creativity.

- Big-c creativity is the creativity of the extraordinarily gifted whose work or thought impacts a field of expertise. Examples include celebrated artists or poets who develop a new genre, or scientists who discover cures for previously incurable diseases.

- Pro-c creativity is the creativity that occurs within a profession, for instance, a head chef who creates a menu of new recipes.

- Little-c creativity is the creativity of everyday life, for instance, songs parents create to calm their children, or projects students create to demonstrate knowledge, understanding or subject skills.

- Mini-c creativity is the creativity experienced by learners as they interact with new information and experiences. Mini-c creativity is often the beginning of more refined creative work and deeper understanding, and is experienced by adults as well as children (Beghetto \& Kaufman, 2007; Kaufman \& Beghetto, 2009; Runco, 2008).

Big-C, pro-c, and little-c creativity rely on external judgments to ascertain and validate originality and appropriateness. In contrast, mini-c creativity does not. When the student experiences it as meaningful or useful, it retains its value and originality, regardless of outside perception (Beghetto \& Kaufman, 2013; Kaufman \& Beg- 
hetto, 2009; Beghetto \& Kaufman, 2007).

This model of creativity supports a strong connection between creativity and learning. It suggests creativity and learning are, in fact, allies. With this understanding it is appropriate to include creativity in our curricula, and important to develop learning environments that support, protect and nourish creativity.

\section{A Classroom Management Plan for Creativity}

While researching my MA dissertation regarding learning environments that support creativity and academic excellence, I read a plethora of articles and books. Many researchers and authors offered theories and suggestions, which though valuable, felt disconnected to my experience in the classroom. Attempting to integrate them into my pedagogy, and implement them into my classroom, felt burdensome.

Then I encountered Teresa Amabile and her theory of KEYS. She suggests managers exert a decisive influence on the work environment, and worker creativity (Amabile, 1998; Amabile, Schatzel, Moneta, \& Kramer, 2004). I immediately thought of teachers as classroom managers. Managers, Amabile asserts, positively impact creativity when they provide their workers with the KEYS of "freedom, positive challenge, supervisory encouragement, work group supports, sufficient resources and organizational support” (Amabile, 1997: p. 8). She suggests this increases intrinsic motivation and creates workers who attain high levels of creativity and achievement (Amabile \& Kramer, 2011; Amabile, 2012).

Amabile's description of managers reads like a job description for teachers. They oversee and appraise work, facilitate distribution of resources and information, and influence and support work group interaction. They set goals, develop knowledge and understanding, and provide assessment. Successful managers value their workers, have faith in their abilities, and are willing to consider ideas even when they are outside the norm (Amabile, Schatzel, Moneta \& Kramer, 2004).

Amabile's theory resonated with me as an educator. Regardless of pedagogy, curricula, testing pressure or school environment, my behavior is under my control. In reality, it is the only thing I truly control in my classroom. It is empowering to consider the potential I have to positively influence my classroom environment, and therefore the creativity and learning of my students.

I have been unable to find evidence of KEYS being researched or suggested as a classroom management plan. I, however, posit it is completely appropriate to extend the use of KEYS to learning environments as a classroom management plan. KEYS has the possibility of creating a positive learning environment of respect and collaboration, where students are valued and enabled to achieve academically and creatively.

Although KEYS has commonly been used in workplace environments rather than learning environments, it is logical to consider using KEYS in the classroom. Teachers are classroom managers. Schools are the work environments of educators and administrators, and although not traditionally envisioned as such, the work environments of students as well. Students spend numerous hours in school each week. They are given tasks to complete, and are expected to meet, or exceed, various achievement and productivity goals. The students are workers who get paid with grades, graduation and the suggestion of a better future.

KEYS offers the opportunity to create a learning environment that encourages students to be personally motivated to explore, think deeply and work hard at academic tasks, while at the same time exercising and growing their creativity. This would enable schools to attain both their academic and creative imperatives while empowering students to love learning. These possibilities compelled me to investigate KEYS further.

\section{Envisioning Amabile's KEYS in the Classroom}

If KEYS is to be used as a classroom management plan, there needs to be an idealized view of the KEYS teacher. To create this image, I adapted Amabile's KEYS. Envisioning the teachers as managers and students as workers, I substituted teacher for manager, and student for worker.

- Freedom: Teachers give students freedom to choose how they will attain the goals set for them. This gives the students a sense of ownership, and in turn increases their intrinsic motivation and engagement (Amabile, Conti, Coon, Lazenby, \& Herron, 1996; Amabile, 1998; Amabile, 2012).

- Positive Challenge: Teachers give their students tasks that match their talents, knowledge and interest. They assign work that is challenging enough to be engaging but not so formidable as to be threatening or overwhelming (Amabile, Conti, Coon, Lazenby, \& Herron, 1996; Amabile, 1998). Optimal levels of challenge are felt by students who believe the task, and the skills used to accomplish it are important and valuable 
(Amabile \& Fisher, 2009).

- Supervisory Encouragement: Teachers work to mitigate stress and provide a learning environment that is free from fear. Goals are clear, appropriate and stable, and progress is monitored with informational feedback rather than criticism. Even when the final result is unknown, the teachers encourage inquiry and exploration, and give free and generous recognition for effort and competence. They value the work and ideas of the students, and act as their champions and advocates. They relate to their students in a collegial fashion, with open and honest interaction and communication (Amabile, Conti, Coon, Lazenby, \& Herron, 1996; Amabile, 1998; Lagace, 2004).

- Work Group Support: Teachers create work groups thoughtfully, and strive to ensure the students experience the work group as challenging but safe. When looking to encourage the generation and exchange of new ideas, they create work groups whose members have a common goal, but diverse expertise and thinking styles (Amabile, Conti, Coon, Lazenby, \& Herron, 1996; Amabile, 1998). Teachers support work group dynamics by helping students understand and appreciate each other's expertise and mindset. Teachers encourage students to ask for, and give, help in their pursuit of work group goals (Amabile, Conti, Coon, Lazenby, \& Herron, 1996; Amabile, 1998; Amabile, Fisher, \& Pillemer, 2014).

- Sufficient Resources: Teachers give their students easy access to quality resources. In this way, they communicate the inherent value of the work, and help the students succeed at their tasks (Amabile, Conti, Coon, Lazenby, \& Herron, 1996; Amabile, 1998).

- Organizational Support: Teachers promote and sustain a shared vision of creativity and productivity for all students. In support of this vision, teachers suggest problem-solving strategies, and encourage risk taking and idea generation. They establish classroom norms of collaboration, and communication, and create and maintain an infrastructure that enables and empowers students to successfully adhere to these norms (Amabile, Conti, Coon, Lazenby, \& Herron, 1996; Amabile, 1998).

\section{Creative Learning Environment Case Studies and KEYS}

If my assertion is correct, and Amabile's framework is as useful in the classroom as it is in the organizations Amabile studied, one should find evidence of KEYS in learning environments that successfully marry creativity and high levels of achievement in learning. Two of the most celebrated creative learning environments are the nucleos of El Sistema and the preschools of Reggio Emilia.

El Sistema, the National System of Youth and Children's Orchestras and Choirs of Venezuela, was founded in 1975 by Jose Antonio Abreu. It is a state-funded musical education program that seeks to re-imagine music as a "catalyst for social transformation" (Hernandez-Estrada, 2012: p. 35). Conductor Gustavo Dudamel's comment highlights the profound trust of youth that informs the work of El Sistema. "Abreu is the creator and we have lots of teachers, but the children are creating the sistema. They are the power of the sistema” (MIT, 2010).

The Reggio Emilia approach to early childhood education was founded in 1963 by Loris Malaguzzi, in Reggio Emilia, Italy. The Reggio Emilia approach is grounded in a powerful image of the child, and a profound understanding of creativity and learning. Reggio Emilia educators celebrate and promote the child as a complex, creative being with an endless desire to know and understand. They affirm and support children's ability to have, and express, their own hypotheses and theories. Much of this work happens in the studio classroom as the children explore materials, ask questions and propose answers (Gandini 2008, Edwards, Gandini, \& Forman, 2012, Rinaldi, 2005).

\subsection{Freedom}

\section{El Sistema}

Autonomy is visible at all levels of El Sistema. Students, teachers, nucleos and even Sistema-inspired programs established outside of Venezuela are afforded the freedom to adapt the program to their unique situation. Work in El Sistema expresses the vision of "constancy of purpose and flexibility of means" (Tunstall, 2012: p. 175).

Students are emboldened to take ownership of their own learning and that of others. From their earliest learning they are encouraged to take what they know and teach others. The learning does not always happen under the guidance or direction of a teacher. Often the student-to-student collaboration of learning occurs spontaneously, outside the classroom as students share what they have discovered with one another. Hernandez-Estrada suggests these frequent moments of student ownership fittingly dissolve the "vertically directive teacher- 
student structures” (Hernandez-Estrada, 2012: p. 94).

Reggio Emilia

Reggio Emilia educators work collaboratively to create learning environments that are "liberated from false boundaries and external caveats" (Edwards, Gandini, \& Forman, 2012: p. 298). They regard children as active participants in their own learning, and give them the freedom "always and everywhere (to) take an active role in the construction and acquisition of learning and understanding” (Edwards, Gandini, \& Forman, 2012: p. 43). This increases the possibility of discovery and allows the children to more fully experience the "joy and triumph of learning” (Vecchi, 2015).

\subsection{Positive Challenge}

\section{El Sistema}

At risk children, special needs children, children with little skills or children with many, are all welcomed, challenged and empowered to succeed within El Sistema. They are envisioned as musicians and orchestral members from the beginning of their El Sistema experience, and even the youngest are exposed to techniques, which are rather advanced. El Sistema educators seek the delicate balance of challenge that is neither too difficult, nor too easy. Orchestral pieces are modified to match the ability of each child, thus giving each child a sense of possibility, while enhancing confidence, and a sense of belonging (Tunstall, 2012).

\section{Reggio Emilia}

Reggio educators make the children's thinking and understanding visible to all through words and photographs. Through this documentation, students revisit their own experiences, and often develop new questions or new understanding. Teachers reflect on the children's experience, and provide the children with opportunities for further exploration and discovery. Children are empowered to undertake tasks of greater complexity with persistence, competence and understanding (Edwards, Gandini, \& Forman, 2012; Cadwell, 2002; Gandini, 2008).

\subsection{Supervisory Encouragement}

\section{El Sistema}

Each child is acknowledged as an asset to their community, their family, their teachers, the orchestra, and to the vision and goals of El Sistema (Hernandez-Estrada, 2012). Students, even those of lesser talents, are afforded respect, expectations, and opportunities, which might otherwise be reserved for the very talented. Tunstall recounts an incident when Carlos Chavez, a famous conductor, came to work with the Caracas nucleo. He worked with the "inexperienced but determined young musicians ... as he would have rehearsed the most seasoned professional musicians ...” (Tunstall, 2012: p. 60).

El Sistema teachers and conductors do not see themselves as other, or separate from the students. Instead they acknowledge being part of a cohesive whole and join the students as partners in the learning process. They model musical excellence, thinking, passion and perseverance, and frequently join in the singing or playing to help and encourage individuals or sections of the orchestra (Tunstall, 2012: p. 253).

Reggio Emilia

Reggio Emilia educators respect and value children—even the youngest. Jerome Bruner commented, "It is like a seminar at the graduate department of the university, with the same kind of respect, of exchange in talking about what you have just said, and about your former thinking” (Rinaldi, 2005: p. 58). Secure in the competency of children, the Reggio Emilia educators enter into a partnership with them, and engage with them as fellow thinkers and researchers of the world. Children and teachers explore, inquire, struggle and learn together (Edwards, Gandini, \& Forman, 2012; Rinaldi, 2005).

\subsection{Work Group Support}

\section{El Sistema}

The orchestra and El Sistema's model of ensemble learning and peer teaching lead to diversity in work groups. Students of different ages, skill levels and musical thinking sit next to each other in practice and the orchestra. El Sistema's policy of inclusion, as well as their insistence on the benefit and necessity of peer teaching, leads the students to understand through experience, that everyone's talent, thoughts and ideas are valuable and worthy of 
consideration. Teachers encourage students to share their knowledge and thinking, and to enter into dialogue regarding it. The diverse work groups of the orchestra, and the orchestra itself, rely on trust, collaboration and hard work. Teachers and students engage in this hard work of learning together. They live the idea that learning is not an individual endeavor but a collaborative responsibility (Tunstall, 2012; Hernandez-Estrada 2012).

\section{Reggio Emilia}

Student work groups in Reggio Emilia are united toward a common, meaningful goal. Teachers believe, and reflect to the students, that it is an advantage to work in groups. They encourage students to share ideas, propose theories and work towards understanding and accomplishment of goals. Teachers, and other adults, sometimes join the groups to work collaboratively with the children. Together they "ask questions of one another, they listen and they answer” (Edwards, Gandini, \& Forman, 2012: p. 46).

\subsection{Sufficient Resources}

\section{El Sistema}

El Sistema students receive instruments, music stands and lessons suited to their particular needs. El Sistema educators and conductors give their knowledge, expertise and passion, as resources, to the students. According to Dudamel, "They don't ever hold back. They want to give you everything they know, everything they feel" (Tunstall, 2012: p. 185).

\section{Reggio Emilia}

Reggio educators provide "an environment rich in materials and possibilities" (Gandini, Etheridge \& Hill 2003: p. 26), and give the children time to explore them both. Often teachers join the children in their journey of discovery and learning-their "faces close to the children's also full of wonder and kindness" (Cadwell, 2002: p.23). They offer information and awareness the children do not yet possess, or perceive, and assist the children so they are not conquered by the materials or techniques (Edwards, Gandini, \& Forman, 2012).

\subsection{Organizational Support}

\section{El Sistema}

El Sistema has a clear shared vision of social transformation through musical education. An infrastructure of collaborative ensemble learning supports the exchange of ideas and attainment of El Sistema goals. Abreu and other leaders consciously share their power with their subordinates. They share ideas, inquire after suggestions and understanding, and support the work and decisions of their subordinates (Tunstall, 2012).

\section{Reggio Emilia}

Reggio Emilia educators have a shared vision of "amiable schools" (Edwards, Gandini, \& Forman, 2012: p. 43). This vision is supported by the infrastructure of the studio classroom rich in resources, their image of the child, and the cultural norms of collaboration, communication and relationships. Collaborative relationships between children, teachers, and families are intentionally supported in the Reggio Emilia system. There is a shared sense of responsibility and power, along with a willingness to enter into dialogue with one another - even across the child-adult and teacher-parent boundaries.

\section{Reflections on KEYS in an Academic Classroom}

I teach kindergarten in an independent, college-preparatory N-12 grade school with an academically rigorous curriculum. Inspired by the results of the two case studies, I interrogated my own practice to discover how KEYS manifest in my classroom, and how they impact my students' creativity and learning.

\subsection{Freedom}

To give my students the opportunity to exercise freedom and discretion I must be reflective in my practice as a teacher. In order to discover where I can prudently, purposefully, and effectively relinquish control I consider two questions. "What is the purpose of the rule, action, behavior or thought process?" and "What might we gain, if I relinquished control and gave my students freedom and autonomy in this instance?"

I also consider the greater purpose of the freedom I grant. I consider how it serves the students, their work and the goal of the classroom and institution. I look for ways it can encourage and enable deeper thought and understanding. Will it allow for greater possibility and creativity? Will it help them achieve their academic goals? 
Will it increase their love of learning? Will it position them for greater thinking and creativity in the future?

There is a Maker Space in our classroom. The supplies are simple but plentiful. The rules are uncomplicated. “Do not make a mess. If you do make a mess, clean up. Be kind. Work together. Be brave. Have fun.” I give my students the freedom — within the rules — to make anything they want.

Given the chance, my students would spend all day, every day, in the Maker Space. Conversation and making abound as they share ideas, offer advice, negotiate for supplies and problem solve together. I often make alongside my students. As I do, I notice, affirm, encourage, and ask questions.

The freedom of the Maker Space often looks and sounds very messy, but it is extremely valuable. My students blossom in the freedom. They gain confidence in their physical and mental abilities. They find problems, and think divergently and convergently to solve them. As they tinker, test, fail, rethink and try again, they experience the value of effort, perseverance and working together. Their hard work, collaboration and communication benefit them and our classroom community.

We do a considerable amount of work on the floor in our classroom. The students sit in a cross-legged position. This provides a stable base, a place to rest one's hands and allows those in the back to see. Unfortunately it is not the most comfortable position for my students or for me. I talked with my students and suggested we try deer pose (legs bent and to the side) as an option when sitting on the floor. One student asked "How about hero (knees bent with ones bottom resting on one's heels)? We're still in our spot with a place for our hands.” I acknowledged their thinking and asked them to think more deeply. "That's true, but we sit much higher in hero. Do you think that would work?" There was a bit of conversation and then another offered, "Maybe we can sit in hero if no one is behind us." Satisfied with their thought process, and comfortable with their suggestion, I responded, "Great idea. So let's amend our rules for sitting on the carpet. We can sit cross-legged, in deer pose, or in hero, if no one is behind us."

Many purposes were served with this discussion and change. Of course one is increased freedom and comfort. But there are more profound results as well. My students experienced freedom and agency. They learned it is important to understand the intent and purpose of rules. They discovered rules are sometimes negotiable. This sets the stage for higher ordered thinking - in the present and the future.

Sometimes I require my students to exercise freedom in their thinking. I ask them to look at something they understand and know to be true-for instance $2+2=4$. Then I ask them to think of an instance when it is, in fact, not true. At first they are incredulous. They are sure it is impossible. I encourage them to think. In a bit they begin to see possibilities. Two hungry girls and two sandwiches equal two full girls. Two dogs and two cats equal sixteen legs.

While whimsical, this is an exercise in critical and creative thinking. I am asking my students to take something they know, and use it in a new way. They have to understand numbers and addition in order to succeed, but cannot be constrained by their current understanding of the rules. This requires deep thinking, openness to possibility and a willingness to search for something they cannot yet see.

This is valuable now, and I hope, in the future. I imagine them as scientists years from now, faced with a problem that appears impossible to solve. Their colleagues are out of ideas and they are considering giving up. One of my students remembers the thinking games we played and says. "I had this teacher in Kindergarten. She told us to be willing to take a risk. She told us things aren't always as they seem. If we understand the rules, we know how to break them appropriately and effectively. I did it then, surely we can do it now!”

\subsection{Positive Challenge}

No one in my classroom may say, "I can’t do this.” Instead, we use our language to more accurately reflect the truth. "This is hard!" "I'm not able to do this yet, but I will!"

This empowers the students to embrace the struggle and problem solve how they might succeed. Sometimes that means asking questions. What do I need? Do I need more information? Do I need practice? Do I need more time? Am I lacking resources? Once they know what they need, they ask for it, and keep trying.

I do my best to allow them to think about, and ask for what they need. I practice this with them in simple, non-threatening ways. They often come to me to tell me they are thirsty. I presume they want to get a drink, but I don't suggest they get one. I simply say, “OK.” Usually they repeat their statement. I smile and say, “OK, did you just want to tell me that, or do you need something?” They always hesitate, as I remain silent. Often they will ask if they can get a drink of water, but sometimes they stop, think, and then say, "Nope, I just wanted to tell you." 
It is a simple case of positive challenge, but it sets the stage for more difficult ones because in that simple exchange my students and I learn something about power and trust. They learn they have the power to think and make decisions. They learn I trust them to do so. I learn they don't always need my help.

It is important for me to see their strength and ability to problem solve and struggle in big and little ways. It encourages me to limit my interference when they are being challenged by a task. I remain cognizant of their level of struggle-like a parent watching her child learn to swim. I definitely do not want them to drown, but I also do not want them to think I doubt them, or am afraid for them. So I smile and allow them to struggle. I encourage. I ask questions. I remind them they have big, beautiful brains and awesome hearts, and I am sure they can do it!

Our Thanksgiving Social Studies unit involved a huge block build. The students worked in three groups to build England and Holland, the Mayflower, and a Native American village. They were relentless in their work. They worked in 30 - 60 minute increments, and often continued during their choice-time.

The build was filled with problem finding and problem solving. How do we create a rounded structure from rectangular blocks? How do we make windmills? How do we create waterfalls? What do squash look like? What do we do when our people don't fit into our house? How do we negotiate when our neighbors want to add more ocean, or more land, and it crosses the line into our area? What do we do when our ideas are different than others in our group? And perhaps most thought-provoking-Where do we put the dead people?

The discussion regarding the dead people arose days after learning some pilgrims perished on the ocean journey. Their discussion was practical: "Nope we do not want to store the dead people where we will be sleeping." and "Maybe we can just throw them in the ocean." But it was also filled with kindness and empathy: "Throwing them into the ocean wouldn't be very nice." They discussed the problem and possible solutions with each other and with me. I didn't offer solutions; I simply encouraged them to keep thinking, talking and problem solving. Eventually they decided the cereal box from our re-usable supplies would work perfectly to hold the dead people.

By limiting my help I allowed them to think, to struggle, to problem solve, and to come up with their own solutions. This allowed them to grow far more than if I had jumped in to save them. They strengthened their problem solving skills. They became better communicators. They learned they could work hard and it could be fun. I learned their brains are even bigger and more beautiful than I imagined.

\subsection{Supervisory Encouragement}

Although my students are only five or six years old, I work hard to establish egalitarian, collaborative relationships with them. I am interested in their thoughts and always respond to their questions of "Can I tell you something?” with "Yes, please tell me something!” I value their stories as a way to get to know them, and I really listen to them as they share. I sit or kneel to speak with them so I am not so far above them, and I often sit on the floor with them when I teach them. This helps us develop a relationship of trust, and ultimately empowers courage, challenge, learning and excellence.

As often as I can, I invite them into the planning process with me. I consider their suggestions and am willing to learn from them. We recently visited a local supermarket to gather information for our next social studies build. Each student filled a small notebook with illustrations and words about the things she saw in the supermarket. Back in our classroom we began discussing the build. We talked about the shape of the store, the many things we saw and how we might proceed. I asked them to think about how we would work on the supermarket once we set up the outside walls. As I spoke, one of them said, "Why do we have to start with the walls?" I responded, "Well, we have to know where the walls are. How will we know how big to make the other things in our supermarket? How will we know how much room we need?" Undeterred, she asked again, "But why do we have to start with the walls? Why don't we start with the things inside?" This time I stopped, and talked with her about her idea. I realized she was right. Why do we have to start with the walls? Why not mark the confines of the building with blue painter tape, and do the walls at the end? A brilliant idea is given to me by a 6 year old.

Blue tape marked the edges of our supermarket as we began the build. I purposefully acknowledged the idea as my student's and not my own mine. I shared how her ideas impacted and changed my ideas and action, and made them better. Each time I do that, I validate my students. They learn their ideas deserve consideration. They learn they can understand and contribute valuable ideas even when they are not "the expert," and they experience the power of "the expert" humbly accepting the ideas of others. 
I often join my students in the work they are doing. I work side by side with them, using the same tools and technique. As I work, I share my process and product with them. Working with a sharpie in art, I shared my reluctance to work on the beautiful, blank pages, afraid I would somehow mess things up. I told my students how free I felt experimenting in the pages of a magazine. I showed them my drawings and talked about my thoughts -what I liked, what I didn't like, how I studied the faces I found in the magazine, and how I eventually developed a face that I liked. I commented that I didn't think it was perfect, but that I really liked it just the same.

My students seemed intrigued by my thought process - especially the fact that I had some fear and reticence. They used my words throughout their work. One student drew something she didn't like and said, "Well, that's ok, I can just go to the next page." Another told me "I'm trusting myself. I'm being brave like you. I'm doing it and just believing it will come out alright." It is amazing to see our relationship, and my words, empower them!

\subsection{Work Group Support}

I support my student work groups by helping them to see each other as assets, and facilitating communication and negotiation. I give them the words they need to self-advocate with strength and kindness. We role-play what to do and say when we think a team member has made a mistake. We practice how to ask for help, and how to give it. We practice waiting to offer help until asked, so our peers can experience the joy of discovery. We talk, a lot, about how what we say and do might make others feel.

\subsection{Sufficient Resources}

I am particular about the resources I offer my students—even, and perhaps most importantly, the paper I give them to do their academic and creative work. I do not give them paper that is wrinkled, ripped or cut askew. When they, or their parents, look at it, they should understand how much I value their work. It may be inexpensive copy paper, but it has been handled with respect and care, and offered to them as a canvas for their thoughts and work.

I frequently bring in my own art supplies to share with my students. I tell them what I like about the supplies-pencils that feel great in my hand, markers that give me beautiful movement across the paper, paint that has vivid color. I explain I decided to share my supplies with them because they are real artists too, and I thought they would enjoy using them. This expresses my respect for them. It strengthens our bonds as co-learners, and co-workers. My hope is it encourages them to be generous with the things they value.

I am a resource for my students. I share my ideas and my excitement. I help them cut things that are too difficult for them. I offer my hands when their hands are too small to hold something. I follow their directions as I help them construct their invention. I do not always feel the need to teach them. Sometimes I just share what I know, or feel, for them to use in the moment, to complete their task.

Time is an incredibly important resource for my students. Time deepens their investigations and thoughts as they hypothesize and experiment. They need time to think, talk, and think some more. They need time to be. Unfortunately, time is often a scarce commodity. I struggle to be creative and intentional as I examine my curriculum and schedule to find time to give to my students.

\subsection{Organizational Support}

The micro-environment of my classroom is impacted by the larger school environment and by the organizational support I provide for my students. As the organizational leader of my classroom, I create its organizational norms, shared vision and infrastructure.

We practice yoga together every Monday. We use affirmations with our breathing. They are positive statements about us as a class, created by the students. "We are strong. We are happy. We always try again. We are not afraid." and "We are peace. We are us. We are kind. We are very nice". We end our practice with gratefulness and affirmation for one another. We make eye contact and say "Namaste. Thank you for practicing. You are awesome”. These powerful words impact my students' perception of themselves, each other, and our classroom.

We have a classroom pledge: "I will work hard, I will play fair, I will be kind”. These classroom norms, combined with my active use of KEYS, support a classroom environment free from fear, where children are empowered to achieve their academic and creative potential. 


\section{Discussion of the Findings}

The findings from the creativity-based classrooms of El Sistema and Reggio Emilia, combined with those of my academically-based classroom demonstrate that creativity and learning are not adversaries, but in fact, strong allies. They highlight the importance of a strong, positive image of the child, and an understanding of the profound potential of creativity and education. They suggest it is not only appropriate, but also valuable, for teachers to use KEYS as their classroom management plan. By providing students with "freedom, positive challenge, supervisory encouragement, work group supports, sufficient resources and organizational support” (Amabile, 1997: p. 8), classroom environments are created that enable students to thrive academically and creatively.

\section{Suggestions for Pre-Service and in-Service Teacher Development}

These findings support the following suggestions for pre-service, as well as in-service, teacher development.

Suggestion 1: Explore the potential of children, and enable a strong, positive view of the child.

Educate, inspire, and challenge the in-service and pre-service teachers to expand their beliefs about children. Explore and explain not only the development but also the potential of children. Illuminate the power and potential of children. Expose the teachers to the joy, passion, wonder and conviction of educators who believe and act upon their beliefs in a strong, powerful child. Study learning environments that have profound beliefs regarding the potential of children. Engage with technology to see what the children are doing, saying and accomplishing as they learn in these other environments. Make books like World Peace and Other 4th Grade Achievements, by John Hunter, required reading.

Suggestion 2: Explore and understand creativity.

Offer classes and workshops on creativity, and creativity in the classroom. Investigate creativity, exploring its relationship with learning. Study learning environments that are integrating creativity and creative thinking into their learning. Examine curricula and schedules to find areas conducive to creativity. Develop curricula that meld standards with creativity. Practice presenting and experiencing these curricula. Invite teachers to experience creativity, and creative thinking, in their own work.

Suggestion 3: Explore and enable an understanding of the profound purpose and possibility of education.

Research what leading thinkers are saying about education and its place in the world. Find and discuss powerful ideas like "Education is the means by which we thrive, individually and collectively" (IDEO, 2015). Empower pre-service and in-service teachers to understand that education, and more precisely, how education occurs, can enable thought, discoveries and innovations that change the world. Elucidate the ways this occurs across grade levels, beginning at the earliest levels.

Suggestion 4: Offer KEYS as a viable classroom management plan

Explore and discuss the ways "freedom, positive challenge, supervisory encouragement, work group supports, sufficient resources and organizational support” (Amabile 1997: p. 8) can occur in the classroom. Examine curricula and school culture, and develop concrete ways to provide KEYS for the students. Consider the potential value of each. Discuss the difficulties one might encounter implementing them. Explore the ways one might overcome these challenges.

Suggestion 5: Encourage and develop personal learning communities

Encourage teachers to work with colleagues to enhance their practice. Develop personal learning communities where pre-service and in-service teachers can discuss their practice and share learning. Help them develop diverse personal learning communities with educators outside their particular learning environment.

\section{Conclusions}

With a strong and positive view of the students, belief in the profound purpose and possibility of creativity and learning, and Amabile's KEYS as their classroom management plan, educators can establish creativity-enhancing learning environments. This will require mind shifts, reflective and intentional practice, and renewed energy. However, in light of the dual imperative of academic achievement and creativity enhancement, combined with the deep need for creativity in our world, it is time to dare to re-imagine the educational landscape.

With these five suggestions, pre-service and in-service professional development can empower teachers to engage with their students in trust and solidarity, and create a place of possibility in their classrooms. Students will be empowered to engage with the opportunities and problems in the world, challenge their perception of 
what is possible, and achieve the impossible. They will, now, or in the future, create innovations that will change the world for the better.

Our students deserve it. Our world demands it.

\section{Acknowledgements}

I am eternally grateful to the people who join me on the journey of research, writing, and teaching. You enhance my thinking, and enrich my research and teaching. Many blessings to you all.

Thanks to Karl Jeffries, Senior Lecturer at University of Central Lancashire for embodying the spirit of Amabile's KEYS. Your guidance in my research and your review of this paper are invaluable.

Thanks to my parents, Rosemary and Harold James for your undying support, many meals and innumerable prayers.

Thanks to my brother, Harry James for letting me use your big, beautiful brain as a resource. Your thoughts and encouragement are essential.

Thanks to my students and their parents (past and present) for joining me on the marvelous journey of creativity and learning. You challenge and encourage inspire me.

\section{References}

Amabile, T. M., Conti, R., Coon, H., Lazenby, J., \& Herron, M. (1996) Assessing the Work Environment for Creativity. The Academy of Management Journal, 39, 1154-1184. http://dx.doi.org/10.2307/256995

Amabile, T. M. (1997). Motivating Creativity in Organizations: On Doing What you Love and Loving What You Do. California Management Review, 40, 39-58. http://dx.doi.org/10.2307/41165921

Amabile, T. M. (1998). How to Kill Creativity. Harvard Business Review. www.hbr.org

Amabile, T. M., Schatzel, E. A., Moneta, G. B., \& Kramer, S. J. (2004). Leader Behavior and the Work Environment for Creativity: Perceived Leader Support. The Leadership Quarterly, 15, 5-32. http://dx.doi.org/10.1016/j.leaqua.2003.12.003

Amabile, T. M., \& Fisher, C. M. (2009). Stimulating Creativity by Fueling Passion, In E. A. Locke (Ed.), Handbook of Principles of Organizational Behavior Indispensable Knowledge for Evidence-Based Management (pp. 481-497). West Sussex, UK: John Wiley \& Sons, Ltd.

Amabile, T. M. (2012). Componential Theory of Creativity. Harvard Business School. http://hbswk.hbs.edu/

Amabile, T. M., Fisher, C. M., \& Pillemer, J. (2014). IDEO’s Culture of Helping. Harvard Business Review.

Amabile, T. M., \& Kramer, S. J. (2011). The Power of Small Wins. Harvard Business Review.

Azzam, A. (2009) Why Creativity Now? A Conversation with Sir Ken Robinson. Journal of Educational Leadership, 67, 22-26.

Beghetto, R. A., \& Kaufman, J. (2007) Toward a Broader Conception of Creativity: A Case for "mini-c” Creativity. Psychology of Aesthetics, Creativity and the Arts, 1, 73-79. http://dx.doi.org/10.1037/1931-3896.1.2.73

Beghetto, R. A., \& Kaufman, J. C. (2013). Fundamentals of Creativity. Educational Leadership, 70, 10-15.

Cadwell, L. B. (2002). Bringing Learning to Life: A Reggio Approach to Early Childhood Education. New York: Teachers College Press.

Cropley, A. (2006). In Praise of Convergent Thinking. Creativity Research Journal, 18, 391-404. http://dx.doi.org/10.1207/s15326934crj1803_13

Edwards, C., Gandini, L., \& Forman, G. (2012). The Hundred Languages of Children: The Reggio Emilia Experience in Transformation (3rd ed.). Santa Barbara, CA: Prager Press.

Gandini, L. (2008). Introduction to the Fundamental Values of the Education of Young Children in Reggio Emilia—Revision. http://www.reggioalliance.org/reggio_related/print_and_video_resources/articles.php

Gardner, H. (1993). Creating Minds: An Anatomy of Creativity Seen through the Lives of Freud, Einstein, Picasso, Stravinsky, Eliot, Graham, and Ghandi. New York: Basic Books.

Hennessey, B. A., \& Amabile, T. M. (1987). Creativity and Learning: What Research Says to the Teacher? Washington DC: National Education Association, Professional Library.

Hernandez-Estrada, J. L. (2012). Aesthetics of Generosity_El Sistema, Music Education and Social Change. Hidalgo, TX: Jose Luis Hernandez-Estrada.

IDEO (2015). Education—Building a Generation of Design Thinkers. http://www.ideo.com/expertise/education/

Kaufman, J. C., \& Beghetto, R. A. (2009). Beyond Big and Little: The Four C Model of Creativity. Review of General Psychology, 13, 1-12. http://dx.doi.org/10.1037/a0013688 
Lagace, M. (2004). How Team Leaders Show Support-Or Not. Harvard Business School Working Knowledge. http://hbswk.hbs.edu/

Mindshift (2015). Sir Ken Robinson: Creativity Is in Everything, Especially Teaching. http://ww2.kqed.org/mindshift/2015/04/22/sir-ken-robinson-creativity-is-in-everything-especially-teaching/

MIT (2010). El Sistema: Social Support and Advocacy through Musical Education (Video). http://video.mit.edu/watch/el-sistema-social-support-and-advocacy-through-musical-education-9553/

Rinaldi, C. (2005). In Dialogue with Reggio Emilia: Listening, Researching and Learning. London: Routledge. http://dx.doi.org/10.4324/9780203317730

Runco, M. A. (2008). Creativity and Education. New Horizons in Education, 56, 107-115.

Torrance, E. P. (1977). Creativity in the Classroom: What Research Says to the Teacher. Washington DC: NEA.

Tunstall, T. (2012). Changing Lives: Gustavo Dudamel, El Sistema and the Transformative Power of Music. New York: WW Norton \& Co.

Vecchi, V. (2015). The Secret of a Raindrop. Proceedings of the Sixth NAREA Winter Conference, New York, 12-14 March 2015.

Wagner, T. (2014). Creating Innovators. https://www.youtube.com/watch?v=6W9oEqp1yi4\&feature=youtu.be\&noredirect=1 